\section{Response to: 'High risk of systemic lupus erythematosus development in patients with ITP: antiphospholipid syndrome is also a concern?' by Inanc et al}

We thank Inanc et $a l^{1}$ for their comments on our article entitled 'Risk of systemic lupus erythematosus (SLE) in patients with idiopathic thrombocytopenic purpura (ITP): a population-based cohort study'. In our article, we concluded that ITP is strongly associated with incidental SLE. ${ }^{2}$

We agree with Inanc et $a l^{1}$ that antiphospholipid syndrome (APS) is an important effect modifier in ITP and SLE. We also acknowledge that Inanc et $a l^{1}$ addressed the difference of APS $(2.77 \%$ in the ITP group vs $0.02 \%$ in the non-ITP controls) in table 1 of our article. ${ }^{2}$ Actually, ITP, APS and SLE sometimes overlapped in clinical practice. As in table 1, there are more baseline comorbidities in the ITP group, including thrombotic event, cardiovascular disease and ITP. Hence, we did propensity score to match these differences rather than exclude these comorbidities in patient selection as in figure 1 . The reason for this is that once you exclude these effect modifiers, then you cannot study their effects. Thus, we prefer matching and stratified analysis on important effect modifiers, rather than exclusion. ${ }^{3}$

As Inanc et $a l^{1}$ mentioned, many claim-based or patientreported databases have concerns of validity and uncertainty. Unfortunately, the National Taiwan Insurance Research Database (NHIRD) did not provide laboratory data, such as antinuclear antibody (ANA) and APS profiles. Although this is a limitation, the NHIRD had been validated and appreciated in many high impact publications. ${ }^{45}$ In our study, we had tried to minimise this information bias by adding sensitivity tests and also stratifies analysis on important confounders, such as thrombosis cardiovascular disease and some infections and life stylerelated diseases to reduce the bias from comorbidities, including APS. These had been discussed in-depth in Discussion section of our article.

Table 1 The crude and age and sex adjusted incidence rate of SLE in general individuals, ITP, Hashimoto's disease, Graves' disease and AlHA population

\begin{tabular}{lrrrr}
\hline Group & $\begin{array}{l}\text { Person- } \\
\text { months }\end{array}$ & $\begin{array}{l}\text { SLE } \\
\text { event }\end{array}$ & $\begin{array}{l}\text { Crude } \\
\text { incidence } \\
\text { rate* }\end{array}$ & $\begin{array}{l}\text { Age and sex } \\
\text { adjusted } \\
\text { incidence rate* }\end{array}$ \\
\hline $\begin{array}{l}\text { General control } \\
\text { (n=14303) }\end{array}$ & 1273883 & 26 & 2.04 & 2.04 \\
$\begin{array}{l}\text { Graves' disease } \\
\text { (n=7345) }\end{array}$ & 650005 & 23 & 3.54 & 3.30 \\
$\begin{array}{l}\text { Hashimoto's } \\
\text { thyroiditis ( } n=1513)\end{array}$ & 118482 & 12 & 10.13 & 15.01 \\
$\begin{array}{l}\text { AlHA (n=121) } \\
\text { ITP (n=697) }\end{array}$ & 6827 & 7 & 102.54 & 39.43 \\
\hline
\end{tabular}

Age and sex adjusted incidence rate, the weighting of standardisation was the age and sex distribution in general control.

* Rate, per 100000 person-months.

ITP, idiopathic thrombocytopenic purpura; SLE, systemic lupus erythematosus.
We agree that APS clinical features and laboratory profiles and ANA are important baseline evaluation for every patient with ITP. It is also indeed our study purpose and conclusion. Furthermore, even though baseline ANA and aPL were negative, we suggest that patients with ITP should still be monitored yearly for clinical and serological lupus or APS. We hope this clinical application will improve the quality of our daily practice.

James Cheng-Chung Wei $\odot$, ${ }^{1,2,3}$ Fang Xiao Zhu, ${ }^{4}$ Jing-Yang Huang ${ }^{1,5}$

${ }^{1}$ Institute of Medicine, Chung Shan Medical University, Taichung, Taiwan

${ }^{2}$ Department of Allergy, Immunology \& Rheumatology, Chung Shan Medical

University Hospital, Taichung, Taiwan

${ }^{3}$ Graduate Institute of Integrated Medicine, China Medical University, Taichung,

Taiwan

${ }^{4}$ Department of Rheumatology and Immunology, The Second Affiliated Hospital of Guilin Medical University, Guilin, Guangxi, China

${ }^{5}$ Department of Medical Research, Chung Shan Medical University Hospital,

Taichung, Taiwan

Correspondence to Dr Fang Xiao Zhu; 1123551518@qq.com

Handling editor Josef S Smolen

Funding The present study was supported by the Programme of Scientific and Technology Project (Guilin Science Research and Technology Development; grant no. 2016012706-2).

Competing interests None declared.

Patient and public involvement Patients and/or the public were not involved in the design, or conduct, or reporting or dissemination plans of this research.

Patient consent for publication Not required.

Provenance and peer review Commissioned; internally peer reviewed.

(c) Author(s) (or their employer(s)) 2020. No commercial re-use. See rights and permissions. Published by BMJ.

\section{Check for updates}

To cite Wei JC-C, Zhu FX, Huang J-Y. Ann Rheum Dis Epub ahead of print: [please include Day Month Year]. doi:10.1136/annrheumdis-2020-218402

Received 24 August 2020

Accepted 25 August 2020

\section{Sinked}

http://dx.doi.org/10.1136/annrheumdis-2020-218345

Ann Rheum Dis 2020;0:1. doi:10.1136/annrheumdis-2020-218402

ORCID iD

James Cheng-Chung Wei http://orcid.org/0000-0003-0310-2769

\section{REFERENCES}

1 Inanç M, Artim-Esen B, Diz-Küçükkaya R. High risk of systemic lupus erythematosus development in patients with ITP: antiphospholipid syndrome is also a concern. Ann Rheum Dis 2020. doi:10.1136/annrheumdis-2020-218345. [Epub ahead of print: 21 Aug 2020].

2 Zhu F-X, Huang J-Y, Ye Z, et al. Risk of systemic lupus erythematosus in patients with idiopathic thrombocytopenic purpura: a population-based cohort study. Ann Rheum Dis 2020:annrheumdis-2020-217013.

3 Chu K-A, Chen W, Hsu CY, et al. Association of scrub typhus with the risk of autoimmune diseases: a population-based cohort study. Am J Epidemiol 2019;188:1311-8

4 Chen M-L, Kao W-M, Huang J-Y, et al. Human papillomavirus infection associated with increased risk of new-onset psoriasis: a nationwide population-based cohort study. Int J Epidemiol 2020;49:786-97.

5 Hsing AW, loannidis JPA. Nationwide population science: lessons from the Taiwan National health insurance research database. JAMA Intern Med 2015;175:1527-9. 